\title{
Methadone Intoxication and Death is a New Disaster
}

\author{
MD Paitoon Narongchai* \\ Department of Forensic Medicine, Chiang Mai University, Thailand
}

*Corresponding author: MD Paitoon Narongchai, Department of Forensic Medicine, Faculty of Medicine, Chiang Mai University, Thailand.

To Cite This Article: MD Paitoon Narongchai, Methadone Intoxication and Death is a New Disaster. 2020 - 8(1). AJBSR.MS.ID.001233.

DOI: $10.34297 /$ AJBSR.2020.08.001233.

Received: 畊 February 27, 2020; Published: 制 March 11, 2020

\section{Introduction}

Methadone was synthesized in Germany from 1937 to 1939 [1,2] and approved in the United States in 1947. [1] Methadone is the most effectiveness which is used in OMT programs [2] and was on the World Health Organization's (WHO) List of Essential Medicines [1,3-6]. Methadone treatment programs has been recommended $80 \mathrm{mg}$ daily dose and $0.4 \mathrm{mg} / \mathrm{L}$ blood concentration which is very good. [6-8] The effects of methadone were 8 to 36 hours [1,3]. The EDDP or 2-ethylidene-1, 5-dimethyl-3, 3-diphenylpyrrolidine, the principle metabolite of methadone, is one of evidence to diagnose the cause of death [9]. The mean blood concentration ratio of methadone to EDDP was 13.6:1 [10]. Respiratory failure, prolonged QT interval, cardiac arrhythmia are caused of death $[1,11,12]$. Benzodiazepines, especially Alprazolam, was the most common combined drugs in methadone intoxication and death [13-19]. The most common drug abuse and related death was heroin and methadone which was $42.4 \%$ and 3.8\%, respectively [20]. Sweden, England, Wales, and Thailand, especially middle-aged man, were increasing of methadone deaths [21-24]. The prescription-related deaths and prescribing patterns are the most common problems in the OMT programs [24-27]. Methadone intoxication alone and death is very rarely reported [28,29]. However, the median lethal concentration of methadone (MLCM) of intoxication and death were reported in OMT and not in OMT were $0.06-2.0 \mathrm{mg} / \mathrm{L}$ and 0.07-0.62 mg/L respectively [29-34]. Methadone related deaths are caused by high incoming doses, increased dosages, and interaction with other drugs, especially benzodiazepines [35,36]. If methadone becomes more widely available for treatment programs, number of deaths will be increased $[24,25,27]$. The MLCM in corpses with deaths ascribed to methadone alone and multiple additional drugs were $0.09 \mathrm{mg} / \mathrm{L}$ and $0.06 \mathrm{mg} / \mathrm{L}$ respectively [37]. The postmortem concentration of methadone increases approximately $20 \%$ in blood after death because it is lipid soluble [38-42]. The solution to prevent prescription-related deaths are using data, providing good communication, methadone prescribing precautions, established standards for chronic prescriptions, and decreasing opioid and benzodiazepine combinations are highly recommended [43]. However, diagnosis cause of death including complete autopsy, pathological examination and toxicological findings are very advantageous and not over estimated [31,44]. The MLCM only related deaths was $0.435 \mathrm{mg} / \mathrm{L}$ [31]. Methadone only related deaths in non-OMT are very rare but combination of alcohol or psychoactive drugs and underlying diseases may have an increased risk of death [45]. However, the patients received excessive starting doses or methadone with take-home doses during the OMT easy died in many cases, especially children [23,46]. The abuse of methadone was usually found in patients who took methadone by themselves. We have many experiences of methadone intoxication which was the only cause of death in non-opioid-maintenance therapy or general population. In the past, this was very rare case in the general population. But we think that methadone intoxication and death will be common cause of death because it is prescribed easily and freely to addicted patients and it is not well controlled. Methadone intoxication and death will be the new disaster drug.

\section{References}

1. (2015) Methadone Hydrochloride. The American Society of HealthSystem Pharmacists.

2. (2015) WHO Model List of Essential Medicines (19th List). World Health Organization.

3. Toombs JD, Kral LA (2005) Methadone treatment for pain states. American Family Physician. 71(7): 1353-1358.

4. Rudd Rose A, Seth Puja, David Felicita, Scholl Lawrence (2016) Increases in Drug and Opioid-Involved Overdose Deaths — United States, 2010- 
2015. MMWR Morbidity and Mortality Weekly Report 65 (50-51): 1445 1452.

5. Li Hui Chen, Holly Hedegaard, Margaret Warner (2014) Age-adjusted drug-poisoning and opioid-analgesic poisoning death rates: United States, 1999-2011. CDC p.8.

6. (2011) Diphenypropylamine Derivatives. Encyclopedia of Drug Policy.

7. Chou R, Turner JA, Devine EB, Hansen RN, Sullivan SD, et al. (2015) The effectiveness and risks of long-term opioid therapy for chronic pain: a systematic review for a National Institutes of Health Pathways to Prevention Workshop. Ann Intern Med 162(4): 276-286.

8. John Strang, Gillian Tober (2003) Methadone Matters: Evolving Community Methadone Treatment of Opiate Addiction. CRC Press pp.320.

9. Baselt R (2008) Disposition of Toxic Drugs and Chemicals in Man (8th ed.). Foster City, CA: Biomedical Publications. pp. 941-945.

10. Jean Paul Bernard, Hassan Z Khiabani, Thor Hilberg, Ritva Karinen ,Lars Slørdal Helge Waal, et al. (2015) Characteristics of methadone-related fatalities in Norway. Journal of Forensic and Legal Medicine 36: 114-120.

11. John S Dowden (2006) Goodman and Gilman's The Pharmacologica Basis of Therapeutics, $11^{\text {th }}$ edition. In: Brunton L, et al. (Eds.), McGrawHill, New York, USA.

12. Sweetman SC (2009) Martindale: The Complete Drug Reference, $36^{\text {th }}$ edition, Pharmaceutical Press, London.

13. (2010) Increases in Methadone-Related Deaths: 1999-2004.

14. (2006) The Killer Cure. The Charleston Gazette.

15. Chen LH, Hedegaard H, Warner M (2014) Drug-poisoning deaths involving opioid analgesics: United States, 1999-2011. NCHS Data Brief 166: $1-8$.

16. Dunn KM, Saunders KW, Rutter CM, Banta-Green CJ, Merrill JO, et al. (2010) Opioid prescriptions for chronic pain and overdose: a cohort study. Ann Intern Med 152(2): 85-92.

17. Charles Day (2014) SAMHSA. Benzodiazepines in combination with opioid pain relievers or alcohol: greater risk of more serious ED visit outcomes. The DAWN report.

18. Cerda M, Ransome Y, Keyes KM, Koenen KC, Tracy M, et al. (2013) Prescription opioid mortality trends in New York City, 1990-2006: examining the emergence of an epidemic. Drug Alcohol Depend 132(12): 53-62.

19. Manchikanti L, Abdi S, Atluri S, Balog CC, Benyamin RM, et al (2012) American Society of Interventional Pain Physicians (ASIPP) guidelines for responsible opioid prescribing in chronic non-cancer pain: part 2guidance. Pain Physician 15(3 Suppl.): S67-S116.

20. (2014) Presidency of the Council of Ministers. Department of Drug Policy. Annual Report to Parliament. Use of drugs and drug addiction in Italy.

21. Wikner BN, Ohman I, Selden T, Druid H, Brandt L, et al. (2014) Opioidrelated mortality and filled prescriptions for buprenorphine and methadone. Drug Alcohol Rev 33(5): 491-498.

22. Handley SA, Flanagan RJ (2014) Drugs and other chemicals involved in fatal poisoning in England and Wales during 2000-2011. Clin Toxicol 52(1): 1-12.

23. Vignali C, Stramesi C, Morini L, Pozzi F, Groppi A (2015) Methadonerelated deaths. A ten year overview. Forensic Sci Int 257: 172-176.

24. Kim T, Small M, Hwang C, Muldrew S (2014) Controlled Substance Utilization Review and Evaluation System-A tool for judicious prescribing. Rx Prev 5(4): 1-8.
25. Centers for Disease Control and Prevention (CDC) (2011) Vital signs: overdoses of prescription opioid pain relievers-United States, 19992008. MMWR Morb Mortal Wkly Rep 60(43): 1487-1492.

26. Kenan K, Mack K, Paulozzi L (2012) Trends in prescriptions for oxycodone and other commonly used opioids in the United States, 20002010. Open Med 6(2): e41-e47.

27. McDonald DC, Carlson KE (2013) Estimating the prevalence of opioid diversion by "doctor shoppers" in the United States. PLoS One 8(7): e69241.

28. Goldberger BA, Maxwell JC, Campbell A, Wilford BB (2013) Uniform standards and case definitions for classifying opioid-related deaths: recommendations by a SAMHSA consensus panel. I Addict Dis 32(3): 231-243.

29. Jean Paul Bernard, Hassan Z Khiabani, Thor Hilberg, Ritva Karinen ,Lars Slørdal Helge Waal, et al. (2015) Characteristics of methadone-related fatalities in Norway. Journal of Forensic and Legal Medicine 36: 114-120

30. Laberke PJ, Bartsch C (2010) Trends in methadone-related deaths in Zurich. Int J Leg Med 124(5): 381-385.

31. Milroy CM, Forrest AR (2000) Methadone deaths: a toxicological analysis. J Clin Pathol 53(4): 277-281.

32. Pilgrim JL, McDonough M, Drummer OH (2013) A review of methadone deaths between 2001 and 2005 in Victoria, Australia. Forensic Sci Int 226(1-3): 216-222

33. Jones AW, Holmgren A, Ahlner J (2012) Blood methadone concentrations in living and deceased persons: variations over time, subject demographics, and relevance of co-ingested drugs. J Anal Toxicol 36(1): $12-18$

34. Hakkinen M, Launiainen T, Vuori E, Ojanpera I (2012) Comparison of fatal poisonings by prescription opioids. Forensic Sci Int 222(1-3): 327 331.

35. Baxter LE, Campbell A, Deshields M, Levounis P, Martin JA (2013) Safe methadone induction and stabilization: report of an expert panel. J. Addict. Med 7(6): 377-386.

36. Madden ME, Shapiro SL (2011) The methadone epidemic: methadone related deaths on the rise in Vermont. Am J Forensic Med Pathol 32(2): 131-135.

37. Steven B Karch, Boyd G Stephens (2000) Toxicology and pathology of deaths related to methadone: retrospective review. West J Med 172(1): $11-14$

38. Hilberg T, Morland J, Bjorneboe A (1994) Postmortem release of amitriptyline from the lungs; a mechanism of postmortem drug redistribution. Forensic Sci Int 64(1): 47-55.

39. Hilberg T, Ripel A, Slordal L, Bjorneboe A, Morland J (1999) The extent of postmortem drug redistribution in a rat model. J Forensic Sci 44(5): 956-962.

40. Ferner RE (2008) Post-mortem clinical pharmacology. Br J Clin Pharmacol 66(4): 430-443.

41. Gerostamoulos D, Beyer J, Staikos V, Tayler P, Woodford N, et al. (2012) The effect of the postmortem interval on the redistribution of drugs: a comparison of mortuary admission and autopsy blood specimens. Forensic Sci Med Pathol 8(4): 373-379.

42. Drummer OH (2004) Postmortem toxicology of drugs of abuse. Forensic Sci Int 142(2-3): 101-113.

43. Roneet Lev, Sean Petro, Oren Lee, Jonathan Lucas, Army Stuck, et al. (2016) A description of Medical Examiner prescription-related deaths and prescription drug monitoring program data. American Journal of Emergency Medicine 34(3): 510-514. 
44. Merril J, Garvey T, Rosson C (1996) Methadone treatment: methadone concentrations taken as indicating deaths due to overdose need to be reviewed. BMJ 313(7070): 1481.

45. (1999) NIH consensus panel recommends expanding access to and improving methadone treatment programs for heroin addiction. Eur Addict Res 5(1): 50-51.
46. SM Marcus (2011) Accidental death from take home methadone maintenance doses: a report of a case and suggestions for prevention. Child Abuse Negl 35(1): 1-2. 